Maurice A. Deane School of Law at Hofstra University Scholarly Commons at Hofstra Law

Hofstra Law Faculty Scholarship

1999

\title{
First Amendment Imperialism (A Response to Michael Walzer's Leary Lecture)
}

Daniel J.H. Greenwood

Maurice A. Deane School of Law at Hofstra University

Follow this and additional works at: https://scholarlycommons.law.hofstra.edu/faculty_scholarship

\section{Recommended Citation}

Daniel J.H. Greenwood, First Amendment Imperialism (A Response to Michael Walzer's Leary Lecture), 1999 Utah L. Rev. 659 (1999) Available at: https://scholarlycommons.law.hofstra.edu/faculty_scholarship/317

This Article is brought to you for free and open access by Scholarly Commons at Hofstra Law. It has been accepted for inclusion in Hofstra Law Faculty Scholarship by an authorized administrator of Scholarly Commons at Hofstra Law. For more information, please contact lawcls@hofstra.edu. 


\section{First Amendment Imperialism}

Daniel J.H. Greenwood*

The First Amendment threatens to swallow up all politics. In the manner of classic social contract theory, First Amendment law asserts the separation of the state from the most salient issues of democratic debate. Increasingly, it acts as a bar to governmental action not just with regard to the issues of conscience and religious practice with which it began, but far into the realm of economic regulation we thought the courts had abandoned to the legislatures after the Lochner ${ }^{1}$ disaster.

Professor Walzer, in this insightful essay, ${ }^{2}$ offers a vision of separationism as the antidote to exclusionary cultural politics gone bad. And he is right. But our First Amendment, here and now as applied in the courts, is more often hostile to any politics at all than supportive of the engaged struggle to create a common life that Professor Walzer celebrates. We need, I think, more of Professor Walzer's separationism in politics-and less of the First Amendment's abstention in law.

Walzer quite correctly points out that the First Amendment's separation of church and state is only a special case of a larger disestablishment: not only religions should be denied "coercive power," but also "racial and ethnic groups, cultural communities, social movements, and even political parties."3 While legal doctrine often treats the Free Exercise and Establishment Clauses as radically separate from each other and the Free Speech Clause, Walzer's account of separationism suggests that we should place the entire Amendment firmly in the core of the liberal effort to create a "civil society" separate from the state. But we also need to restrain the First Amendment so that it protects rather than displaces politics; we need to transform it from an individualistic

'C Daniel J.H. Greenwood, Professor of Law, University of Utah College of Law. Thanks to Professor Walzer, who showed me the difference between the problem of legitimacy and the problem of peace, and to Robert Cover, $z^{\prime} l$, who taught me the difference between worlds that stand on Torah, work, and deeds of kindness, see Pirke Avot 1:2, THE MISHNAH: A NEW TRANSLATION 673 (Jacob Neusner trans., 1988), and those that stand on justice, truth, and peace, see id. 1:18 at 675. This comment explores a First Amendment often seen as standing on universal values of justice, sometimes on truth and, in my understanding of Walzer's talk, on peace. But the particularisms of a set of historical traditions, peculiar modes of work, and deeds of kindness to fellow countrymen cannot be avoided. For help in my own peculiar modes of work, I owe thanks to many of my colleagues and especially to Karen Engle and Carol Salem:

${ }^{1}$ Lochner v. New York, 198 U.S. 45 (1905).

${ }^{2}$ See Michael Walzer, Drawing the Line: Religion and Politics, 1999 UTAH L. REV. 619.

${ }^{3} I d$. at 632. 
protector of a sphere of privacy into a political guarantor of decent collective politics.

What is needed, then, is an account of the First Amendment as a whole-as a unified program of separationism and limited government. Considering the First Amendment in this way, it seems to me, helps not only to illuminate the Amendment's effect on the specific debates Walzer addresses (most especially, the role of politics and religion in the schools, old-age homes, hospitals and similar social institutions) but also to understand First Amendment imperialism-its rapid expansion into areas long thought impervious to constitutional law.

Classically, separation of church and state has been understood as the epitome of the classic liberal approach-making politics safe by making it trivial. Separation, on this view, stands for a demand that the government of the people and by the people not define the people. It insists that the classic goals of politics-defining a collective space, creating a people and a culture, defining what makes us one and different from foreigners-are beyond the bounds of our state. Non-liberal political theory has often emphasized those aspects of law understood in the Greek concept nomos or the Hebrew halakhah: the law, first and foremost, should concern itself with the creation of a national way of life or a common culture. ${ }^{4}$ In contrast, the First Amendment calls for governmental abstention, retreat, shrinking to make space for civil society. ${ }^{5}$

Thus, Rousseau, attacking the thin liberal program, describes an ideal legislator who imposes upon his citizens a "yoke of iron ... filling up every moment of their lives" in order to "transform[] them into beings more than merely human" by "distinctive usages," "exclusive and particular" religious ceremonies, etc., to make them a distinctive nation that cannot be swallowed up by another, or happy anywhere else. ${ }^{6}$ The First Amendment program is

${ }^{4}$ Nomos, the normative universe, is explored in Robert M. Cover, The Supreme Court, 1982 Term-Forward: Nomos and Narrative, 97 HARV. L. REv.4 (1983). Halakhah, the system of Jewish law, literally means "path" or "way of walking" and, indeed, Jewish law classically saw its purview as extending to every aspect of life. In these and other pre-liberal traditions, law encompassed what we would more likely refer to as culture, tradition, morality, decency and even taste. The "culture wars" were the central task of politics, interest group conflicts or the pursuit of efficiency a minor sideshow at best.

${ }^{5}$ Compare the Kabbalistic doctrine of the tzimtzum-God's voluntary self-containment necessary to make room for the world. See, e.g., GERSHOM SCHOLEM, SABBATAI SEVI: THE MYSTICAL MESSIAH 29, 31 (1973) (describing tzimtzum).

'JEAN-JACQUES ROUSSEAU, THE GOVERNMENT OF POLAND 7-11 (Willmoore Kendall trans., 1985). 
quite different: let the law be limited, pale, abstract. Passion and particularity are too dangerous, too likely to end in what Walzer calls "politics gone bad."

This abstentious First Amendment is fundamentally anti-political, in that it seeks to remove vast areas of human communal existence from the political process. ${ }^{8}$ The problem of culture is no longer to be the central question of collective life but rather a private matter for individuals acting according to their individual consciences. Or, for those whose religions require action in community, ${ }^{9}$ or whose artists are more actively social participants in an ongoing enterprise than the solitary geniuses of Romanticism, culture is to be a product of people cooperating or interacting in civil society without benefit of state support.

In a society that has become suspicious of politics and a legal culture that tends to view political struggle as simply an unprincipled, unprofessional and sloppy version of courtroom procedure, the First Amendment principle of abstention has expanded beyond a program of making politics safe to become a primary vehicle in a post-New Deal attempt to reduce the scope of conscious collective control over the market. The First Amendment, understood in this way as a fundamental limitation on the scope of government, has become the locus of a new Lochnerism-or rather, a revival of the old Lochnerism under a new doctrinal label. The courts have increasingly begun to use the First Amendment to restrict economic regulation and enforce a vision of the market freed not from politics "gone bad," but rather from all politics altogether.

Indeed, today the most important aspects of the First Amendment as legal doctrine are not its restrictions on state establishment of churches or its protections for political speech. The realities of coalition politics in a winnertake-all system of large single member districts would probably make establishment at the federal level impractical in any event, while intra-

${ }^{7}$ See Walzer, supra note 1 , at 632.

${ }^{8}$ Of course, I don't mean to mean to suggest that abstention is neutral, or inevitable, or natural or pre-political or anything of that sort, nor am I suggesting that law is self-interpreting or endowed with meanings apart from its political context. The anti-politics of the First Amendment is also political, in the sense that it is the result of concrete political struggles over the proper realm of democratic politics and legislative supremacy. By calling it anti-political, I mean to claim that the separationist program seeks to replace a politics of popular debates, coalition building, compromise and voting with, instead, law applied by judges attempting to answer the question of the limits of government by interpretation of legal materials, seeking to explicate "best meanings" rather than to create winning popular coalitions.

${ }^{9}$ While First Amendment cases often seem to treat religion as an entirely individual affair, the image of the solitary soul following the dictates of conscience is not natural for religions that, for example, require prayer to be in public. 
governmental competition would limit it at the local level. It was not the First Amendment that ended the blue laws. ${ }^{10}$

Similarly, recent First Amendment restrictions on state interference with religious practices are of limited realistic significance: as cases such as

${ }^{10}$ The Sunday blue laws, banning work, drinking and other activities on Sunday, have declined from their peak in Puritan Massachusetts Bay to mere vestigial remnants, such as bans on the sale of beer before noon. The courts, however, had little to do with this process: they consistently found legally enforced Sunday observances to be something other than an establishment of religion. See, e.g., McGowan v. Maryland, 366 U.S. 420, 445 (1961) (upholding statute that barred "profaning the Lord's Day" as secular in motive and effect and stating that "scores" of cases had so held). But see Rogers v. State, 4 S.E.2d 918, 919-20 (Ga. Ct. App. 1939) (upholding Sunday [sic!] laws on claimed authority of the Ten Commandments); Ex parte Newman, 9 Cal. 502, 502 (1858) (holding California's Sunday law unconstitutional for discriminating against Jews and Seventh-Day Adventists who view the Fourth Commandment as binding), rev'd, Ex parte Andrews, $18 \mathrm{Cal}$. 678, 685 (1861) (upholding similar law).

Similarly, the ending of legal disabilities on Catholics, Jews and other non-Protestants has proceeded largely without assistance from the courts. Thus, the courts have upheld apparent legal disabilities while the legislatures have overturned them. See, e.g., Goldman v. Weinberger, 475 U.S. 503, 510 (1986) (upholding military regulation requiring military officer to remove his yarmulka in violation of religious law); Stansbury v. Marks, 2 Dall. 213, 213 (Pa. 1793) (imposing fine on witness who "refused to be sworn, because it was his Sabbath"); 10 U.S.C. $\$ 744$ (1988) (overruling Goldman); VA. CODE ANN. § 18.2-343 (Michie 1996) (1849 statute exempting Jews from Sunday blue laws). See also City of Boerne v. Flores, 521 U.S. 507,559 (1997) (O'Connor, J., dissenting) (noting that "legislatures apparently believed that the appropriate response to conflicts between civil law and religious scruples was, where possible, accommodation of religious conduct," but not citing much judicial accommodation).

The combination of repeated judicial holdings that Sunday and Christmas are secular holidays with the view that minority practices are religious without regard for their meaning within the minority culture has the consequence that governmental celebration of majority holidays raises few First Amendment questions while recognition or accommodation of minority traditions nearly always does. See, e.g., Lynch v. Donnelly, 465 U.S. 668, 679, 683 (1984) (holding that Christmas is "National Holiday" celebrated by western world and that crèche can be secular, with no discussion of status of members of nation who believe that a mass celebrating the birth of Christian Messiah is a religious event and wish to celebrate it (or not) as such). Compare, e.g., County of Allegheny v. A.C.L.U., 492 U.S. 573, 643 (1989) (Brennan, J., dissenting) (stating that Jewish symbols, like the Hanukkah menorah [sic: the symbol in question was a nine-branched hanukkiah], are "indisputably" religious without noting that Hanukkah, a festival celebrating a victory in a war of national liberation, is not a "holy-day" (yontif) in the dominant Jewish tradition). The Court seems to take the view that peculiar customs or needs of minority groups are necessarily religious, while religiously-based customs of the majority are presumptively secular, thus making the Establishment Clause an obstacle to encouraging the broadening of American self-definition to include all the nation. For another example, see Bauchman v. West High Sch., 900 F. Supp. 254, 268 (D. Utah 1995) (treating Christian religious song as secular and Hebrew-language secular Israeli song as religious). 
Kiryas Joel ${ }^{11}$ and Employment Division v. Smith ${ }^{12}$ demonstrate, the legislatures, by and large, have been more sympathetic to minority religions than the courts. Nor have the courts been particularly protective of minorities when the legislatures were not: Lukumi, not Reynolds, seems to be the outlier. ${ }^{13}$ In each of these areas, the primary protection for minorities is the political culture of abstention-the fact that parties that propose to impose religious or cultural uniformity upon us usually lose the election-not the legal doctrines of the First Amendment. ${ }^{14}$

"See Board of Educ. of Village of Kiryas Joel Sch. Dist. v. Grumet, 512 U.S. 687, 705 (1994) (voiding as establishment New York Legislature's attempt to meet secular special educational needs of Satmar Hasidic children). The New York Legislature repeatedly attempted to avoid this decision. See 1994 N.Y. Laws (ch. 241), N.Y. EDUC. LAW $\S 1504$ (McKinney 1988 \& Supp. 1999) (allowing formation of new school district); Grumet v. Cuomo, 90 N.Y.2d 57 (1997) (invalidating 1994 version of $\S 1504$ ); 1997 N.Y. Laws (ch. 390) (reenacting modified version of $\S 1504$ ); Grumet v. Pataki, 675 N.Y.S.2d 662, 666 (N.Y. App. Div. 1998) (invalidating 1997 version of $\$ 1504$ ). In light of the Supreme Court's abandonment of Aguilar v. Felton, 473 U.S. 402 (1985), overruled by Agostini v. Felton, 521 U.S. 203, 337 (1997), it may now be possible to accommodate the Satmar needs administratively. The more serious establishment problem Kiryas Joel raises is centrally within Walzer's understanding of a broader separationism even when it is not doctrinally within the Establishment Clause: that is, the treatment of minorities within any relatively homogeneous political unit. See, e.g., Waldman v. Village of Kiryas Joel, No. 97-C7506, 1999 U.S. Dist. LEXIS 2824 at **4-5 (S.D.N.Y. 1999) (discussing challenge of "dissident" regarding "the pervasive and unconstitutional entwinement between secular and religious affairs in Kiryas Joel"); Kahal Charidim Kiryas Joel v. Village of Kiryas Joel, 935 F. Supp. 450, 452 (S.D.N.Y. 1996) (discussing challenges to village's zoning ordinances by minority within minority).

${ }^{12}$ See Employment Div. v. Smith, 494 U.S. 872, 888-90 (1990) (upholding criminal ban on use of peyote with no exception for religious use), overruled by OR. REV. STAT. $\$ 475.992$ (1993) (creating exception for religious peyote use). Congress attempted to overturn Smith more generally by the Religious Freedom Restoration Act of 1993 ("RFRA"). See 42 U.S.C. $\S \S 2000 \mathrm{bb}-2$ to $2000 \mathrm{bb}-4$. The Court held RFRA unconstitutional in Boerne, 521 U.S. at 536.

${ }^{13}$ Compare Church of the Lukumi Babalu Aye, Inc. v. City of Hialeah, 508 U.S. 520, 545-46 (1993) (protecting Santeria sacrifices against municipal ban), with Reynolds v. United States, 98 U.S. 145, 161-66 (1878) (refusing to protect Mormon polygamy against congressional ban in first U.S. Supreme Court First Amendment case); see also Lyng v. Northwest Indian Cemetery Protective Ass'n, 485 U.S. 439, 458 (1988) (permitting Forest Service, over its own EIS objections, to pave road in Native American holy site); Smith, 494 U.S. at 890 (upholding criminal ban on use of peyote with no exception for religious use). Historically, as well, the political culture of disestablishment has been more protective than the legal doctrine. Thus, for example, the last recorded blasphemy case, Commonwealth v. Kneeland, 37 Mass. 206, 221 (1838), upheld the statute; the demise of this crime came at the hands of the executive and legislative branches.

${ }^{14}$ Sometimes, of course, the courts have made important contributions to the ongoing debate on the proper meaning of political separationism and even led rather than trailed the general political culture. See, e.g, West Virginia St. Bd. of Educ. v. Barnette, 319 U.S. 624, 642 (1943) (protecting Jehovah's Witnesses' right not to say pledge of allegiance); Engel v. Vitale, 370 U.S. 421, 436 (1962) (overturning Regent's Prayer); School Dist. of Abington 
In contrast, the First Amendment is immensely important in purely economic matters that may not seem to have anything to do with freedom of speech or religion, but are critical limitations on the scope of politics. ${ }^{15}$ The Speech Clause of the First Amendment now bars most forms of campaign finance reform, ${ }^{16}$ requires that states permit price competition in sales of pharmaceutical drugs, ${ }^{17}$ requires states to allow advertising of out-of-state commercial transactions that would be illegal if conducted in-state, ${ }^{18}$ restricts anti-blockbusting regulation, ${ }^{19}$ requires allowing utilities to use rate-payers money to promote increased energy use despite a governmental policy of conservation, ${ }^{20}$ limits governmental regulation of guns and liquor, ${ }^{21}$ bars most traditional State Bar bans on lawyer advertising, ${ }^{22}$ requires cities to allow

Township v. Schempp, 374 U.S. 203, 225-26 (1963) (striking down Lord's Prayer and Bible readings as religious exercises in schools); $c f$. N.H. REV. STAT. ANN. $§ 194: 15-9$ (1989) (1975 statute purporting to authorize recitation of Lord's Prayer in schools as "affirmation of religious freedom"). But in the most controversial area-the public schools-the current modus vivendi, a kind of watered down multiculturalism in which thin versions of many religions' holidays are celebrated, was created outside the courts and seems at best questionable under the separationism models the Court has promoted.

${ }^{15}$ For commentary on the expansion of the commercial speech cases to encompass much of the old economic due process results, see Daniel A. Farber, Commercial Speech and First Amendment Theory, 74 Nw. U.L. REV. 372, 379-84 (1979); Thomas H. Jackson \& John Calvin Jeffries, Jr., Commercial Speech: Economic Due Process and the First Amendment, 65 VA. L. REV. 1, 40 (1979); David F. McGowan, A Critical Analysis of Commercial Speech, 78 CAL. L. REV. 359, 444-48 (1990); Frederick Schauer, Commercial Speech and the Architecture of the First Amendment, 56 U. CIN. L. REV. 1181, 1193-95 (1988); Steven Shiffrin, The First Amendment and Economic Regulation: Away from a General Theory of the First Amendment, 78 NW. U. L. REV. 1212, 1226-27 (1983).

${ }^{16}$ See Buckley v. Valeo, 424 U.S. 1, 43, 44 (1976) (holding that spending money is speech); compare Young v. New York City Transit Auth., 903 F.2d 146 (2d Cir.), cert. denied, 498 U.S. 984 (1990) (holding that begging for money is not speech).

${ }^{17}$ See Virginia State Bd. of Pharmacy v. Virginia Citizens Consumer Council, 425 U.S. 748,771 (1976).

${ }^{18}$ See Bigelow v. Virginia, 421 U.S. 809, 826-29(1975) (overturning criminal conviction for advertising abortion services in state where they were then illegal).

${ }^{19}$ See Linmark Assocs., Inc. v. Township of Willingboro, 431 U.S. 85, 98 (1977) (voiding ban on residential "For Sale" signs).

${ }^{20}$ See Central Hudson Gas \& Elec. Corp. v. Public Serv. Comm'n, 447 U.S. 557, 569-72 (1980) (voiding New York's ban on utility promotion of increased use of electricity, adopted during 1973 energy crisis).

${ }^{21}$ See, e.g., 44 Liquormart, Inc. v. Rhode Island, 517 U.S. 484, 516 (1996) (restricting liquor advertising ban); Rubin v. Coors Brewing Co., 514 U.S. 476, 490-91 (1994) (voiding ban on advertising malt liquor alcohol content); Nordyke v. Santa Clara County, 110 F.3d 707, 710-13 (9th Cir. 1997) (voiding contractual bar on gun shows).

${ }^{22}$ See Zauderer v. Office of Disciplinary Council, 471 U.S. 626, 650-53 (1985). But see Florida Bar v. Went For It, Inc., 515 U.S. 618, 633-35 (1995) (upholding limited ban on lawyer solicitation as time, place and manner regulation). 
businesses to install advertising-flyer distribution-stands on street corners, ${ }^{23}$ limits libraries' evictions of people who use them as flop-houses, ${ }^{24}$ prevents states from restricting corporations they create from lobbying (even if the lobbying is effectively mandated by state corporate law) ${ }^{25}$ limits the degree to which New York City can regulate panhandling, ${ }^{26}$ prevents California from restricting commercial exploitation of the names of crime victims and criminals, ${ }^{27}$ and even prevents citizens from requiring milk companies to disclose whether they are feeding cows artificial hormone supplements. ${ }^{28}$ If the milk additive case is not a fluke, apparently all consumer protection acts are constitutionally suspect, and if that is so, it is hard to see why much of the civil rights acts and the entire securities regulatory scheme would not be as well. ${ }^{29}$

${ }^{23}$ See City of Cincinnati v. Discovery Network, Inc., 507 U.S. 410, 430-31(1993) (requiring that city treat advertising flyers as if they were as important as newspapers). The First Amendment seems to require states to allow sidewalk news racks selling newspapers. See, e.g., Sentinel Communications Co. v. Watts, 936 F.2d 1189, 1207 (11th Cir. 1991). The two rules together, then, mandate permitting advertising machines as well.

${ }^{24}$ See Kriemer v. Bureau of Police, 765 F. Supp. 181, $197-98$ (D.N.J. 1991) (finding that library decorum rules violated First Amendment right of homeless man), rev'd, 958 F.2d 1242, 1251-64 (3d Cir. 1992) (upholding library's rules only after lengthy First Amendment analysis).

${ }^{25}$ See First Nat'l Bank v. Bellotti, 435 U.S. 765, 794-95 (1978) (overturning state statute forbidding expenditures by business corporations to "influence[] the vote on referendum proposals"); Consolidated Edison Corp. v. Public Serv. Comm'n, 447 U.S. 530, 544 (1980) (finding that "Commission's suppression of bill inserts that discuss controversial issues of public policy directly infringes upon First Amendment freedom of speech rights"); see also Daniel Greenwood, Essential Speech: Why Corporate Speech Is Not Free, 83 Iowa L. REv. 995 (1998) (arguing that even political speech by publicly traded corporations promotes no First Amendment value).

${ }^{26}$ See Loper v. New York Police Dep't, 999 F.2d 699, 704 (2d Cir. 1993) (holding that begging is a protected communicative activity subject to First Amendment protections and cannot be banned on city streets or parks); see also Young v. New York City Transit Auth., 903 F.2d 146 (2d Cir. 1990) (reversing decision by distinguished lower court judge that held that panhandling in the subway was a protected First Amendment activity).

${ }^{27}$ See Los Angeles Police Dept. v. United Reporting Corp., 146 F.3d 1133 (9th Cir. 1998), cert. granted, 119 S. Ct. 901 (1999).

${ }^{28}$ See International Dairy Foods Ass'n v. Amestoy, 92 F.3d 67, 72 (2d Cir. 1996) (holding that statute requiring purely factual disclosure of presence of milk from rBST treated cows "contravenes core First Amendment values" because state had not sufficiently proven that widespread consumer concern was well grounded); see also Cal-Almond, Inc. v. United States Dep't of Agriculture, 14 F.3d 429, 434 (9th Cir. 1993) (almond marketing program); United States v. Frame, 885 F.2d 1119, 1132-33 (3d Cir. 1989) (federal Beef Promotion \& Research Act), cert. denied, 493 U.S. 1094 (1990); National Comm'n on Egg Nutrition v. Federal Trade Comm'n, 570 F.2d 157, 164 (1997) (right not to present anything but the "pro-egg" position).

${ }^{29}$ The civil rights acts are centrally directed at limiting "expressive behavior" sending a political message that certain groups are not full members of our political community. See, e.g., R.A.V. v. City of St. Paul, 505 U.S. 377, 393 (1992) (overturning hate speech ordinance 
The Religion Clauses have not been quite as aggressively expansionist, but the state RFRAs, assuming they are not held unconstitutional, seem likely to change that history. Already, some courts have found that RFRA, its state equivalents, or the Religion Clauses themselves restrict the degree to which cities can protect historic buildings ${ }^{30}$ and provide services to disabled schoolchildren. ${ }^{31}$ One member of the Supreme Court has even suggested that RFRA might preclude enforcement of civil rights acts. ${ }^{32}$ More will follow: we have already seen, for example, claims that taxes violate religious principles. ${ }^{33}$ No doubt there is a similar plaintiff for any other action a legislature might take.

In each of these instances, the First Amendment as applied by the courts displaces electoral politics in an area that has little to do with the struggles of John Peter Zenger and William Pitt for political and legal freedom. The Court's First Amendment requires that these political issues be left to nonpolitical processes of civil society: only the market, not political struggle, may decide how much liquor or legal advertising there will be or whether milk manufacturers will honestly disclose the contents of their product. This is abstention not to make politics safe but to destroy it altogether.

Justice Scalia ends his opinion in Boerne saying, "[S]hall it be the determination of this Court, or rather of the people, whether [exceptions shall be made to generally applicable laws for religious needs]. It shall be the people." ${ }^{34}$ But what he holds is that the meaning of the Establishment Clause is beyond the rule of the people and indeed beyond the sphere of politics. The First Amendment, in the name of preserving the underpinnings of political self-government, is replacing politics with law.

Lochner, then, has returned. Once again, our Court is trying to solve the problems of our joint economic life by interpreting the principles of liberal abstention. But the rules of living together are too complicated for that: interpretation asks what the First Amendment means, while we should be

because "the burning of a cross does express a message"). The securities regulation regime is a pure example of prior restraint. If the First Amendment were applied fully to either of these areas, existing law would be affected at least as radically as was libel law, see New York Times Co. v. Sullivan, 376 U.S. 254 (1964) or campaign contribution law, see Buckley v. Valeo, 424 U.S. 1 (1976), when the First Amendment reached them.

${ }^{30}$ See Flores v. City of Boerne, 73 F.2d 1352, 1355 (5th Cir. 1996), rev'd sub nom City of Boerne v. Flores, 521 U.S. 507 (1997).

${ }^{31}$ See Kiryas Joel, 512 U.S. at 693.

${ }^{32}$ See Swanner v. Anchorage Equal Rights Comm'n, 513 U.S. 979, 979 (1994) (Thomas, J., dissenting) (suggesting that certiorari should have been granted).

${ }^{33}$ See Jimmy Swaggart Ministries v. Board of Equaliz., 493 U.S. 378, 384 (1990) (claiming that sales tax infringed on religious freedom to sell books).

${ }^{34}$ City of Boerne, 521 U.S. at 2176 (Scalia, J., concurring). 
asking, instead, how can we best live together in a world where some (but not all) of us want to separate libraries and flop-houses, assure that the invisible hand of the market motivates individuals to promote, not destroy, the public good, or control corporations to preclude their becoming human creations that coerce their creators needlessly and unthinkingly? The Court's First Amendment stands in the way of this political struggle, by claiming that the difficult compromises of political life can be avoided, independently of the people concerned, as a matter of pure principle. By asking the wrong question, it assures that we cannot reach the right answer.

$* * *$

Walzer, however, seeks not to abolish politics but to tame it. How then is his abstention different from the classic liberal fence around politics the Court has struggled to apply?

The First Amendment is sometimes viewed as a kind of equal protection amendment for religions, requiring that religious individuals not be discriminated against. Alternatively, it is viewed as creating a zone of privacy for the individual conscience. Either view taps into a rich tradition of controversy over issues such as the baseline from which equal treatment is to be measured: How can the state be neutral in a world where the state and the legal systems routinely interfere everywhere else? Or formal and substantive equality: Is it enough that everyone be treated the same, or must different people be treated differently? Both views tend, however, to be highly individualistic, centering on the needs or rights of individuals taken quite separately from the religious and cultural groups to which they belong.

Walzer's analysis is particularly helpful in its reminder that the problem of separation is centrally one of political coexistence, not merely philosophic interpretation. ${ }^{35}$ Although he uses the language of individual rights, his ultimate concern is best understood as not one of legal rights at all. It is, rather, the issue of finality. The key to separationism, he tells us, is that politics must be an ongoing process of negotiation, discussion, debate, conflict, persuasion and controversy in which no resolution is reached and no victory is allowed. ${ }^{36}$

In this political analysis, state neutrality is not to be understood as a philosophic concept susceptible of precise definition or a legal principle elucidated by logic and precedent. Rather, the issue is one of a political culture-maintaining a space for today's winners to lose tomorrow. The former view led straight to the imperialist First Amendment, in which 
abstention functions to force us to abandon the effort to tame the less pleasant aspects of a market economy in the name of individualism; the latter leads to a different First Amendment, designed to promote a politics of inclusion.

This is not a rights argument at all. Victorious political movements, Professor Walzer tells us, may enact their program but not their party; so too religions. ${ }^{37}$ The disestablishment principle, in this broad form, is the grounding of the democratic system, perhaps the most centrally important part of the Constitution-the Republican Form of Government Clause made operational ${ }^{38}$ - and yet virtually unenforceable except in the consciences of the victors. ${ }^{39}$

It is, instead, an argument directed to victorious groups, telling them to remember not to treat their opponents as Satanic threats to civilization or even representatives of all that is wrong in society-even when they are wrong-but rather as fellow members of a common enterprise. Ultimately, it is only that understanding of fellowship-not legal rights, court-enforced neutrality, or even traditional morality-that will keep us from the "politics gone bad" of the Wars of Religion or their twentieth-century equivalents. American and South African apartheid alike survived in the face of welldeveloped legal and moral systems; even the ultimate horrors of Nazi Germany were rather more supported than resisted by judges and church leaders. Once groups were defined out of membership, legal rights did them no good: slaves were property, Jews were vermin, and no legal system is organized to support slaves or vermin.

The key to Walzer's vision, it seems to me, is found in this concept of membership. Organizations, nations and societies all distinguish between members and outsiders. Outsiders are treated as means to be exploited: they are inputs to be used as efficiently as possible to get as much out of them as possible. When inputs get more, the organization has less: think of the normal way that business corporations think of their employees or suppliers. But members cannot be treated that way. A member is not an input but an end in itself: when members are better off, the organization is better off. The key, then, to decent politics is to ensure that when we refer to "us," or "we," or the "nation," we are referring to all of us. That all of the formal citizens (and perhaps all the inhabitants, or even more) of the country are treated as members whose welfare the state seeks to maximize, not as outsiders to be exploited for the benefit of members. And that the state (and we, in our roles as voters, debaters and citizens) takes all of us to be ends not means.

${ }^{37}$ See id. at 634.

${ }^{38}$ See U.S. CONST., art. IV, $\S 4$.

${ }^{39}$ Witness the abject failure of the courts to restrict political gerrymandering except by the most formalistic of rules. 
This vision of separationism as directed to maintaining a sense of mutual membership in a common enterprise is quite different from the more common view of separation as creating a sphere from which government is excluded. Walzer's explanation has a major advantage over the leading legal theories of the First Amendment: it explains one of the most puzzling aspects of existing doctrine-the radical dichotomy between the treatment of religion in the schools and elsewhere. The state routinely provides funds for churchrun hospitals and old-age homes, even when they are pervasively religious. At the same time, even seemingly trivial subsidies to church schools are problematic and often held unconstitutional. Neither of the leading legal theories explain this distinction: on the "wall between church and state" model, the payments to church hospitals and old-age homes seem clearly improper, regardless of whether or not the details of the Lemon test are applied. ${ }^{40}$ Similarly, on the equal protection model, the school cases are clearly wrong, since they sanction clear preference for secular private (and public) schools relative to religious ones (and certainly treat parents who wish to send their children to religious schools far worse than those who prefer public schools).

Walzer, in contrast, offers a clear justification for treating schools differently: they-but not the adult and especially the end-of-life institutions-raise the spectre of a movement invoking the state to perpetuate itself. ${ }^{41}$ From the perspective of the liberal privatization theory of abstention, though, Walzer's answer only raises a further puzzle. The First Amendment as conventionally understood is a list of bans on governmental action, areas excluded from political struggle and left to civil society. The logic of the First Amendment, then, offers a clear and simple answer to the problem of "finality" in the schools: privatize them, by a voucher system universally and equally available to all students and all schools. Taxpayers would still support education, of course, but they should do so according to the norms of the First Amendment: by creating an open forum. The state would be out of the business of impressing ideologies on young minds and politics would be tamed, if not entirely eliminated, as the issue of how to educate the next generation went the way of the established church. Neither kulturkampfs nor fits of spite would mar our educational politics.

Privatized schools, like the church-run nursing homes Walzer endorses, would come in many flavors. Domination by one group would be virtually impossible: if a group imposed a catechism in its schools, all those parents (or older children) who dislike the specifics, or catechisms generally, would

\footnotetext{
${ }^{40}$ See Lemon v. Kurtzman, 403 U.S. 602, 612 (1971) (setting out four-part test for determining when wall of separation between church and state has been breached).

${ }^{41}$ See Walzer, supra note 1 , at 635-36.
} 
simply leave. The market would assure both a variety and, one can safely assume, not too many too strict catechisms.

Walzer does not address vouchers, except indirectly and by a counterproposal: church schools, he says, should not be supported by state funds when they are teaching church (or ethnic) doctrine, but, he notes, he could imagine clerics coming into the public schools to teach religion (and presumably ethnicity). ${ }^{42}$ Now, this is precisely contrary to current First Amendment doctrine, which seems far more likely to accept voucher-funded private schools than officially hired church educators in the state schools. Why does he come out this way?

Walzer's transformation of abstention into a tool to promote, not ban, politics provides an answer, I think. Privatizing school would, it seems to me, predictably worsen, not improve, our political life.

First, private schools will naturally be led by those most committed to the particular particularisms of each school. Those who care most about sectarianism are those most likely to teach it. The result will be a large increase in the number of children exposed to extreme versions of the various sectarian particularisms that make up the American people. ${ }^{43}$

In contrast, the danger in our public schools is mush, not sectarianism. Public schools must find one curriculum that fits all, or at least does not evoke too much protest. The inevitable tendency is to drive out the extremists and purists (they can go to private school), leaving the moderates to find some meeting point in the mushy middle. Vouchered private schools would each educate deeply to some particular American sectarianism; public schools have jumped at the thinnest variety of multiculturalism - on Tuesday we do one sub-culture and on Wednesday another, all stripped of anything that might make them offensive or too difficult to understand.

Public school multicultural mush is not the best way to get a deep or critical education. But it does tend to reduce our cultural differences, or at least to accustom our children to finding the common elements. Segregated as our public schools are, it is nonetheless hard, at least in the city schools, not to meet parents and children from significantly different backgrounds. In class together for four or six years, we have little choice but to find ways of

${ }^{42}$ See id. at $636 \mathrm{n} .33$.

${ }^{43}$ Something similar to this seems to have happened in the religious (public) schools in Israel, where the first generation of teachers came from backgrounds well to the political and religious right of the parents who sent their children. When the children came to maturity, their views were far closer to those of their teachers than to their parents. See generally SEF RACHLEVSKY, HAMORO SHEL MASHIAH [MESSIAH'S DONKEY] (1998) (discussing rise of Messianic extremism in Israel). 
coexistence. That experience is the beginning of the decent politics Walzer seeks. Vouchered private schools would eliminate this training ground.

Neither avoiding coercion nor abstention nor even Walzer's fear of finality can justify the public schools. Funding students rather than schools would be less coercive, at least to the parents, since they would be able to pick the schools they want. The children probably would be exposed to more religiously, ideologically or culturally charged schools than today, but it does not seem sensible to call this coercion: the concept of ideological or cultural coercion makes little sense applied to children who do not yet have a formed ideology. The resulting plethora of fissiparous sectarianisms, perhaps more thickly understood than today's, would be unlikely to create a self-perpetuating finality. Anarchy and chaos, not the totalitarianism Walzer fears, seem more likely.

The justification is, rather, the value of affirming our common membership. If we seek to live together, we should put in the effort to build a common school system, making the compromises necessary to keep both our religious and nonreligious, culturally committed and assimilationist, families in the system. The voucher model is an American version of the Ottoman Millet system, in which different communities lived side by side but did not interact. A political community should aspire to more.

But building a common school system means compromise. And in the current reality of the United States, it probably must include some compromises that the Supreme Court has barred. We cannot return to the bad old days in which one religious group was able to define its particular customs and practices as neutral; rather, we must find spaces for many differences to come into the schools. Watered down it will inevitably be: there is not time in the school day for anything else. Perhaps, as Walzer suggests, ${ }^{44}$ it should include bringing different religions into the schools for different kids, or comparative religion study for all, or in the more conventional American approach, coordinated release time. The key is to find a solution that more of us can live with, and to find it in the world of friendship, not abstract principles.

More generally, this understanding of separationism can point the way to a different First Amendment: one that promotes politics instead of displacing it. ${ }^{45}$ Freedom of speech and religion should be seen as foundations

${ }^{44}$ See Walzer, supra note 1 , at 636 n.33.

${ }^{45}$ I've tried to apply this political understanding of abstention to a different issue, not conventionally understood as arising under the First Amendment but clearly closely related, in an article on the abortion problem. See Daniel Greenwood, Beyond Dworkin's Dominions: Investments, Memberships, The Tree of Life and the Abortion Question, 72 TEXAS L. REV. 559 (1994) (arguing for political, rather than principled, solution). 
for a political project of finding a way to live together based in real dialogue, not as philosophic or legalistic alternatives to messy compromises. We should embrace separationism to make politics safe, but not to pretend that we can make ourselves safe from politics, for living together always involves conflicts of values that cannot be avoided by false neutrality.

Justice, it turns out, is both too much-we cannot achieve it for everyone short of the messianic era-and too little. What we need is mutual concern. 